Seção Temática: Balanço do Fundeb

Volume 10 - $2020 \mid$ n. 25

\title{
Repercussões do Fundeb no Acesso e na Oferta da Educação Infantil: um estudo de caso ${ }^{1}$
}

\author{
Josielli Teixeira de Paula Costa \\ Franceline Rodrigues Silva \\ Daniel Santos Braga \\ Universidade Federal de Minas Gerais (UFMG), Belo Horizonte/MG - Brasil
}

\section{Resumo}

Este artigo tem como objetivo discutir o Fundeb e suas repercussões no acesso de crianças de 0 a 5 anos em creches e pré-escolas, assim como nas condições de oferta desta etapa da educação básica. Foi realizado um estudo de caso em um município de Minas Gerais, a partir de análise documental e de dados com tratamento estatístico. O município de Ribeirão das Neves foi escolhido tendo em vista seu porte demográfico em relação a seu PIB. O recorte temporal compreendeu os anos de 2009 a 2019, com marco inicial a Emenda Constitucional 59. Foram estabelecidas três categorias de análise: expansão das matrículas, infraestrutura das escolas e remuneração docente. Revelou-se que o Fundeb se tornou a principal fonte de receitas da educação do município. Demonstrou-se que o fundo possibilitou: a expansão de creches e pré-escolas, o crescimento do número de crianças matriculadas, o aumento da contratação de professores e a melhoria da infraestrutura geral dos estabelecimentos.

Palavras-chave: Fundeb. Educação Infantil. Condições de oferta. Direito à educação.

\section{Repercussions of Fundeb on Access and Supply of Early Childhood}

\section{Education: a case study}

\section{Abstract}

This article aims to discuss Fundeb and its repercussions on the access of children from 0 to 5 years old in kindergartens and preschools, as well as on the conditions of provision of this stage of basic education. A case study was carried out in a city of Minas Gerais, from documental analysis and secondary data with statistical treatment. The city of Ribeirão das Neves was chosen considering its demographic size in relation to its GDP. The time frame encompassed the years 2009 to 2019, with Constitutional Amendment 59 as the starting point. Three categories of analysis were established: expansion of enrollment; school infrastructure; and teaching salaries. It was revealed that Fundeb has become the main source of income for education in the city. It was shown that the fund made possible: the expansion of childcare centers and pre-schools; the growth in the number of children enrolled; the increase in the hiring of teachers; and the improvement of the general establishments infrastructure.

Keywords: Fundeb. Early Childhood Education. Conditions of offer. Right to education.

\footnotetext{
1 Este artigo contou com financiamento da Coordenação de Aperfeiçoamento de Pessoal de Nível Superior (CAPES) e do Conselho Nacional de Desenvolvimento Científico e Tecnológico (CNPq).
} 
Repercussões do Fundeb no Acesso e na Oferta da Educação Infantil

\section{Introdução}

A Constituição Federal de 1988 (CF/88) e a Lei de Diretrizes e Bases da Educação Nacional (LDB), Lei 9.394, de 20 de dezembro de 1996, estabelecem o atendimento escolar de crianças de 0 a 5 anos como parte do direito subjetivo à educação. A partir desses marcos, os municípios, responsáveis pela oferta da educação infantil, passaram a ampliar a oferta a essa etapa a partir da expansão de suas creches e pré-escolas. Porém, essa expansão ainda está aquém da demanda (PINTO; DUARTE; VIEIRA, 2012; OCDE, 2017) permanecendo fora da educação escolar muitas crianças de 4 a 5 anos e um número ainda maior de crianças de 0 a 3 anos (OPNE, 2018).

Uma das explicações para esse déficit está no fato de os municípios, entes federativos com menor capacidade fiscal (ARRETCHE, 1999), concentrarem a maior parte das matrículas da educação infantil, não conseguindo, assim, destinar recursos suficientes para garantir o atendimento da demanda de crianças em suas redes. Ainda que nas últimas décadas o País tenha elevado os investimentos para a ampliação do atendimento da educação infantil, especialmente após as mudanças advindas com o Fundo de Manutenção e Desenvolvimento da Educação Básica e Valorização dos Profissionais da Educação (Fundeb), permanecem grandes desafios e obstáculos à universalização dessa etapa da educação básica.

O Fundeb surgiu como um instrumento de política de redistribuição orçamentária com o objetivo de reduzir desigualdades históricas da capacidade de estados e municípios de ofertarem os serviços de educação (ARELARO, 2007). Herdeiro do Fundo Nacional de Manutenção e Desenvolvimento do Ensino Fundamental e de Valorização do Magistério (Fundef), que vigorou entre 1997 e 2006, o Fundeb é um fundo contábil composto por recursos estaduais e municipais. A política de fundos teve um importante efeito redistributivo em Minas Gerais, ao garantir recursos mínimos para o atendimento educacional nos municípios do estado e amenizando as desigualdades regionais (BRAGA; SILVA, 2019). No entanto, os efeitos do Fundeb não se deram da mesma maneira nas diferentes etapas e modalidades educacionais.

Este artigo tem como objetivo discutir as repercussões do Fundeb na educação infantil no tocante ao acesso de crianças de 0 a 5 anos em creches e pré-escolas, assim como nas condições de oferta desta etapa da educação básica. Para isso, optou-se por fazer um estudo de caso do município de Ribeirão das Neves, quarta maior cidade em população da região metropolitana de Belo Horizonte/MG, com um dos mais baixos Produto Interno Bruto (PIB) per capita da região $\left(22^{\circ}\right.$ em 34 municípios) e um dos municípios mineiros que mais recebe aportes do Fundeb. Inicialmente, foi feita uma análise sobre a trajetória histórica da educação infantil no Brasil, e de seu financiamento. Em seguida, procedeu-se a caracterização do município de Ribeirão das Neves em seus aspectos históricos, demográficos e econômicos assim como sua capacidade institucional de investimento em educação. Por fim, realizou-se análises de frequências estatísticas dos dados educacionais, a fim de se conhecer melhor a realidade da educação infantil de Ribeirão das Neves e desvelar as condições de acesso e oferta da educação infantil do município. 
Repercussões do Fundeb no Acesso e na Oferta da Educação Infantil

\section{Breve Histórico da Educação Infantil no Brasil: a trajetória secular até a promulgação do direito}

A educação das crianças pequenas no Brasil tem suas origens no século XIX, em 1875, quando foi fundado o primeiro jardim de infância, no Rio de Janeiro (NUNES; CORSINO; DIDONET, 2011). Outra iniciativa ainda nesse século foi a criação do Instituto de Proteção e Assistência à Infância do Brasil (IPAI), fundado na então capital em 1899. O IPAI tinha como objetivos atender crianças com menos de oito anos; educar as mães com noções básicas de higiene para cuidar melhor dos seus filhos; vacinar as crianças; regulamentar o trabalho das mães trabalhadoras em indústrias e incentivar a criação de instituições como creches e jardins de infância (KRAMER, 1984; FREIRE; LEONY, 2011).

Nas primeiras décadas do século XX surgiu o Departamento da Criança no Brasil (DCB), que se dedicou ao amparo à criança e à gestante por meio da elaboração de levantamentos estatísticos, o zelo pelo cumprimento das leis, promoção de iniciativas e congressos nessa área. O Primeiro Congresso Brasileiro de Proteção à Infância promovido em 1922 pelo DCB reuniu representantes da iniciativa privada e do poder público e alertava à necessidade de superação daquele momento em que a atenção às crianças era majoritariamente exercida pelo trabalho de instituições privadas de caridade, recomendando a aprovação de legislação específica relativa aos direitos da criança (NUNES; CORSINO; DIDONET, 2011). Os participantes do Congresso ainda apontaram para a premência de garantir-se para as mães trabalhadoras em seus locais de trabalho um espaço apropriado à amamentação dos seus filhos, evidenciando a carência de ações e políticas de amparo e assistência à infância (NUNES; CORSINO; DIDONET, 2011).

Somente em 1940 foi criado o primeiro programa estatal de proteção à maternidade, à infância e à adolescência no Brasil - o Departamento Nacional da Criança (DNCr), vinculado ao Ministério da Educação e Saúde (KRAMER, 1984). Basicamente o DNCr em seu tempo de existência teve todos os seus objetivos e competências direcionados a atuar e contribuir para a proteção da maternidade, infância e da adolescência, atuando na realização de estudos, fiscalização de atividades promovidas no País, estimulação e organização de estabelecimentos estaduais, municipais e particulares. Em inquérito realizado pelo $\mathrm{DNCr}$ na década de 1940, citado por Vieira (1988), é evidente a atuação indireta do Estado na administração de instituições pré-escolares nesse período, pois em um total de 29 creches pesquisadas ao redor do país durante o inquérito não se constatou nenhuma com caráter totalmente público, estando elas no encargo de associações particulares, empresas, congregações religiosas e da Legião Brasileira de Assistência (LBA).

O histórico de construção do direito à educação infantil no País também é marcado pela atuação da LBA, criada no ano de 1942 com a missão inicial de prestar auxílio às famílias dos convocados para a II Guerra Mundial (CAMPOS; ROSEMBERG; FERREIRA, 1995). Com o fim da Guerra e o passar do tempo, o foco inicial de atuação da LBA modifica-se. Uma das marcas dessa mudança é a criação pela LBA, do Projeto Casulo, em 1977, como o primeiro programa de educação infantil em massa no País, chegando em 1977 a atender 1.709.020 crianças, registrando uma evolução no atendimento de mais de $1.000 \%$ comparando-se ao atendimento do programa no ano da sua criação (ROSEMBERG, 2006). De abrangência nacional, o Projeto Casulo estava presente em muitos municípios do país, seus objetivos se 
Repercussões do Fundeb no Acesso e na Oferta da Educação Infantil

encontravam na assistência e desenvolvimento integral da criança (ROSEMBERG, 2006), sendo que, para seu funcionamento, bastava um espaço ocioso, simples e precário; pessoas leigas da comunidade exercendo atividade voluntária nas instituições e alocação de recursos financeiros ínfimos em relação aos custos reais de uma creche (CAMPOS; ROSEMBERG; FERREIRA, 1995).

Apenas na década de 1970 nasceram iniciativas do Ministério da Educação em direção à educação da criança pré-escolar. Foi criado em 1975 o Setor de Educação Pré-escolar, tornando nesse mesmo ano a Coordenação de Educação Pré-escolar e depois Coordenadoria de Educação Pré-escolar (CAMPOS; ROSEMBERG; FERREIRA, 1995). O ano de 1981, por sua vez, é marcado pela criação do Programa Nacional de Educação Pré-escolar, incluindo, além das secretarias de estado da educação, o atendimento pré-escolar público no País por meio de baixo investimento orçamentário, instituições e oferta alternativa e envolvimento da comunidade nas instituições, atuando com trabalho voluntário ou semivoluntário (CAMPOS; ROSEMBERG; FERREIRA, 1995).

Após a ditadura militar houve uma intensa mobilização popular em prol dos direitos sociais na expectativa de que essas demandas fossem reconhecidas no texto da nova CF/88 (NUNES; CORSINO; DIDONET, 2011). No tocante à educação das crianças pequenas, para a Assembleia Nacional Constituinte foi criada a Comissão Nacional Criança e Constituinte com a finalidade de construir propostas para o novo texto constitucional (NUNES; CORSINO; DIDONET, 2011). Passados mais de cem anos da fundação do primeiro jardim de infância no País, com a promulgação da CF/88, a garantia da educação infantil às crianças de 0 a 6 anos em creches e pré-escolas torna-se uma condição para o Estado brasileiro cumprir o seu dever em relação ao direito social à educação. A LDB representa a extensão legal da disposição constitucional do direito à educação para a primeira infância, reconhecendo a educação infantil como primeira etapa da educação básica, incluindo pré-escolas e creches no sistema educacional.

\subsection{Financiamento e educação infantil: uma história de exclusão e inclusão na política de fundos}

O reconhecimento da educação infantil como direito da criança, opção da família e dever do Estado (BRASIL, 1988) e primeira etapa da educação básica (BRASIL, 1996a) não foi suficiente para integrá-la ao Fundef e, por conseguinte, excluiu as creches e pré-escolas da redistribuição de recursos subvinculados à educação por dez anos. O Fundef inclusive é apontado na literatura como responsável pelo subinvestimento em educação infantil, significando, em termos práticos, nos munícipios, o declínio de matrículas nas pré-escolas, fechamento de creches e o surgimento de distorções remuneratórias nas redes de ensino entre professores do ensino fundamental e da educação infantil (SILVA, 2017; SANTOS; SOUSA JUNIOR, 2016; COSTA; DUARTE, 2008).

Apesar das análises que já alertavam para os prejuízos causados pelo Fundef à educação infantil ao focalizar exclusivamente o ensino fundamental, a inserção das creches no Fundeb não foi imediata. A Proposta de Emenda à Constituição n ${ }^{\circ} 415 / 05$ enviada pelo governo federal ao Congresso Nacional, em junho de 2005, mesmo dispondo sobre organização dos Fundos e a distribuição proporcional de seus recursos entre as modalidades e etapas da educação básica, no seu artigo $2^{\circ}$, inciso VII, $\S 1^{\circ}$, excluía a totalidade de 
Repercussões do Fundeb no Acesso e na Oferta da Educação Infantil

matrículas nas creches do Fundeb, ainda que tal segmento fosse considerado junto a préescola primeira etapa da educação básica desde 1996:

\begin{abstract}
§ 10 Para efeito da distribuição de recursos dos Fundos a que se refere o inciso II do caput, levar-se-á em conta a totalidade das matrículas no ensino fundamental e considerar-se-á, para a pré-escola, para o ensino médio e para a educação de jovens e adultos, um quarto das matrículas no primeiro ano de vigência dos Fundos, metade das matrículas no segundo ano, três quartos das matrículas no terceiro ano e a totalidade das matrículas a partir do quarto ano (BRASIL, 2005, grifo nosso).
\end{abstract}

A supressão da educação das crianças de 0 a 3 anos e da valorização remuneratória dos seus professores no texto da PEC $n^{0} 415 / 05$ só foi revertida com a mobilização de mais de duzentas entidades da sociedade civil (SANTOS, 2015; DIMENSTEIN, 2005). Uma das ações do movimento "Fundeb pra Valer - Direito à educação começa no berço e é pra toda vida", ocorreu no dia 31 de agosto de 2005 e

[...] reuniu cerca de 500 mães, bebês e crianças, representantes de diversos movimentos sociais, organizações empresariais, sindicatos e ativistas do campo educacional no Congresso Nacional. $\mathrm{O}$ ato começou por volta das $11 \mathrm{~h}$ desta quartafeira, 31 de agosto, com uma carreta de carrinho de bebês subindo a rampa do Congresso. Depois, as falas dos participantes se intercalaram com chocalhaço, fraldas pintadas e uma grande ciranda no hall principal da Câmara (DIMENSTEIN, 2005, online).

O empenho do Movimento "Fundeb pra Valer!" resultou na incorporação, no conjunto de textos legais que regulamentam o Fundeb, do cômputo das matrículas de toda a educação básica, incluindo as creches na redistribuição de recursos da principal fonte de financiamento da educação básica.

Criado pela Emenda Constitucional $n^{\circ} 53$ de 2006 e regulamentado pela Lei de $n^{\circ}$ 11.494/2007, o Fundeb, além de contemplar toda a educação básica na distribuição dos recursos em suas diferentes etapas e modalidades de ensino, igualmente amplia a cesta de impostos e percentual abarcados para composição do fundo em relação ao seu antecessor, o Fundef.

Fora o quantitativo de matrículas nas redes de educação básica, aspecto considerado na logística de distribuição dos recursos que compõem os fundos, cabe considerar os distintos fatores de ponderação das matrículas por etapa, modalidade de ensino, na oferta em tempo parcial ou integral. Em 2007, por exemplo, ano de criação do Fundeb, a creche $(0,80)$ e préescola $(0,90)$, junto da educação de jovens e adultos $(0,70)$, padeciam com os menores fatores de ponderação, enquanto o ensino médio em tempo integral e o integrado à educação profissional $(1,30)$, os melhores (BUENO; PERGHER, 2017). No transcorrer de nove anos, 2007 a 2016, contudo as creches e pré-escolas foram os segmentos mais ascendentes em termos de fator de ponderação, de acordo com análise de Bueno e Pergher (2017):

Sintetizando e comparando os dados apresentados neste texto percebe-se que as maiores modificações, desde 2007 até o ano de 2016, encontram-se na área da educação infantil. Verifica-se que a modalidade creche, além de várias ramificações, tem sido a que apresentou as maiores mudanças, sendo elas: creche pública integral, de 0,80 para 1,30; creche pública parcial, de 0,80 para 1,00 e creche conveniada integral, de 0,95 para 1,10 . Permanecendo sem mudanças apenas a ponderação de creche conveniada parcial que se manteve, desde 2007, com seu fator em 0,80. Do mesmo modo, realizou-se a análise das mudanças na modalidade pré-escola, sendo estas: pré- 
Repercussões do Fundeb no Acesso e na Oferta da Educação Infantil

escola integral, de 0,90 para 1,30 e pré-escola parcial, de 0,90 para 1,00 (BUENO; PERGHER, 2017, p. 13).

O aumento do fator de ponderação das creches e pré-escolas, se por um lado pode ser considerado mais um avanço para o financiamento da primeira etapa da educação básica, especificamente no que toca à política de fundos, por outro é contestável e/ou insuficiente, haja vista ser a educação infantil a etapa mais onerosa de toda a educação básica, cuja responsabilidade de atuação é dos municípios, ente mais frágil em termos arrecadatórios (CARA, 2014). Aliás, os avanços legais no âmbito da educação infantil e de seu financiamento são intimidados pelos grandes desafios a serem enfrentados pela etapa, que perpassam o aumento da oferta de vagas em creches, a universalização do atendimento em pré-escolas, a melhoria da qualidade das instituições, a garantia de melhores condições de trabalho para as professoras e profissionais dedicadas ao cuidado e educação de bebês e crianças pequenas (SILVA; BRITO, 2019).

\section{Caracterização do Município de Ribeirão das Neves}

O Município de Ribeirão das Neves está localizado no vetor norte da região metropolitana de Belo Horizonte (RMBH). Possui uma população de aproximadamente 334.858 habitantes, sendo considerado o $4^{\circ}$ município mais populoso dentre os 34 municípios que integram a RMBH. Com uma extensão territorial de $155,454 \mathrm{~km}^{2}$, o município é dividido em três macrorregiões: o distrito de Justinópolis, a regional Centro e a regional Veneza.

Ribeirão das Neves possui um estigma de cidade-dormitório, tais cidades ou bairrosdormitórios são áreas que possuem, além de um baixo dinamismo econômico, uma alta proporção de movimentos pendulares da população, que se desloca a cidades próximas por diferentes motivos, geralmente estudo ou trabalho (SOSA, 2018).

\subsection{Aspectos históricos, demográficos e econômicos}

Segundo o Instituto Brasileiro de Geografia e Estatística (IBGE), as primeiras referências sobre Ribeirão das Neves são do início do século XVIII, quando se denominava Matas de Bento Pires. No ano de 1745, o mestre de campo Jacintho Vieira da Costa recebeu os direitos das terras, onde construiu um engenho e uma capela dedicada à Nossa Senhora das Neves. A Lei Providencial de 15 de setembro de 1827, reforçada pelo Decreto de 11 de setembro de 1830, elevou Neves a Distrito de Paz, com uma população aproximada de 1.241 habitantes.

Em 1846, Neves perdeu sua condição de distrito devido às condições precárias da capela e o aumento da população. Foi criado, então, o distrito de Venda Nova, ao qual Neves foi anexado. Posteriormente, Neves foi anexada ao distrito de Pindahybas, atual Vera Cruz de Minas (Pedro Leopoldo), no qual permaneceu até 1911, quando ambos foram anexados ao recém-criado município de Contagem. Em 1927, o Estado de Minas Gerais adquiriu parte da Fazenda de Neves para a construção de uma Penitenciária Agrícola (PAN). A construção da penitenciária aumentou a população e teve sua inauguração em 1938 como Penitenciária Agrícola de Neves (PAN). Após fazer parte de vários municípios, a região foi elevada à categoria de município em 12 de dezembro de 1953, pela Lei n. ${ }^{\circ} 1.039$, com a denominação de Ribeirão das Neves. 
Repercussões do Fundeb no Acesso e na Oferta da Educação Infantil

Segundo Silva e Stephan (2015), a construção da PAN desempenhou papel fundamental na estruturação espacial da cidade, pois, além de concentrar população ao seu redor, ela significou um referencial forte da paisagem para a população.

Sendo assim, até os dias atuais o município de Ribeirão das Neves lida com problemas que foram ocasionados desde o desenvolvimento do seu núcleo urbano. A incapacidade financeira e técnica, aliada ao crescimento populacional desordenado, serviços urbanos inadequados, a ausência de mão de obra qualificada e o estigma de cidade presídio (atualmente são sete unidades prisionais) não favoreceram a instalação de indústrias e de grandes centros comerciais no território nevense. Esse cenário afetou significativamente a qualidade de vida da população e contribuiu para a grande dependência econômica do município em relação à Belo Horizonte.

Outro ponto importante é que o crescimento desordenado e a concentração populacional num cenário de estagnação econômica acarretam diversos problemas, entre eles o aumento da demanda por empregos sem simultâneo aumento da oferta, tendo como consequência a elevação das taxas de desemprego, queda na renda e empobrecimento da população. De acordo com o Censo Demográfico (2010), apenas 9,3\% da população nevense possui uma ocupação e $34,5 \%$ da população vivem com rendimento nominal mensal de até meio salário mínimo. Além disso, a cidade conta com um alto índice de comércio e trabalho informais, que, aliados à baixa taxa de ocupação, repercutem na arrecadação municipal de impostos próprios, como, por exemplo, o Imposto Predial e Territorial Urbano (IPTU) e o Imposto sobre Serviços.

Segundo Gomes (2018), Ribeirão das Neves apresentou no ano de 2017 um nível de adimplência de $53 \%$ do IPTU, ou seja, apresentou níveis de arrecadação muito abaixo das cidades do mesmo porte. Sendo assim, apesar de ser uma cidade de porte médio em população, Ribeirão das Neves é caracterizada como um município pobre.

\subsection{Recursos públicos vinculados e investimento em educação: o papel do Fundeb no financiamento da educação infantil em Ribeirão das Neves}

Como exposto, Ribeirão das Neves pode ser enquadrada como um município com baixa capacidade institucional de atendimento educacional por ter uma grande população em idade escolar e, ao mesmo tempo, uma arrecadação tributária própria relativamente pequena. Assim, o município, ao longo do tempo, se tornou bastante dependente de transferências constitucionais, conforme pode ser observado na Figura 1. 
Repercussões do Fundeb no Acesso e na Oferta da Educação Infantil

Figura 1 - Composição das receitas correntes de Ribeirão das Neves em relação à origem

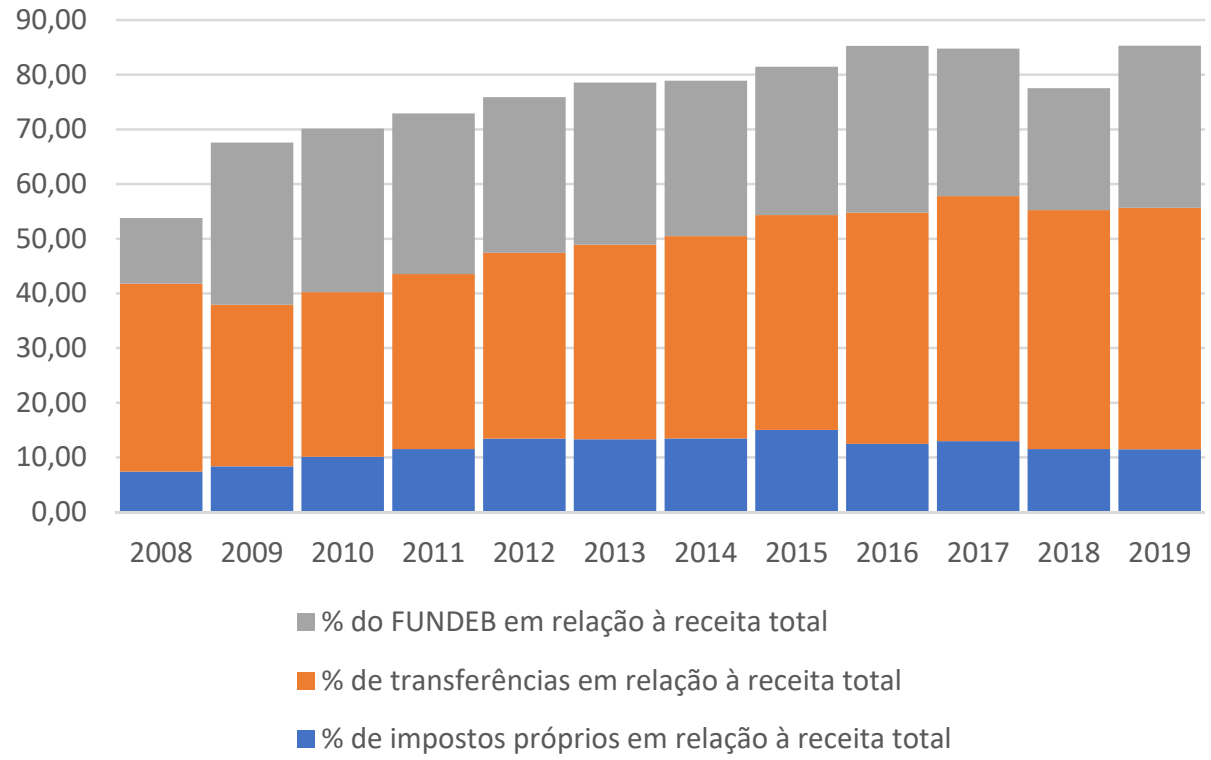

Fonte: Elaboração dos autores a partir do SIOPE.

Dessa forma, os dados apontam que o Fundeb se tornou uma importante fonte de recursos para o município desde sua implementação, compondo parte significativa das transferências recebidas pelo município.

O gráfico da Figura 2 revela que o saldo financeiro do Fundeb, isto é, a diferença entre o montante destinado para a composição do fundo e o total recebido, foi se tornando mais acentuado ao longo do tempo. O único período de queda (2011 a 2013) diz respeito à crise fiscal vivida pelo estado de Minas Gerais no período, que se caracterizou pela redução de arrecadação de ICMS e repercutiu na diminuição de transferências intragovernamentais, bem como a do Fundeb (BRITO; BRAGA, 2006).

Figura 2 - Saldo financeiro do Fundeb de Ribeirão das Neves, corrigido pelo IPCA, dez./2019

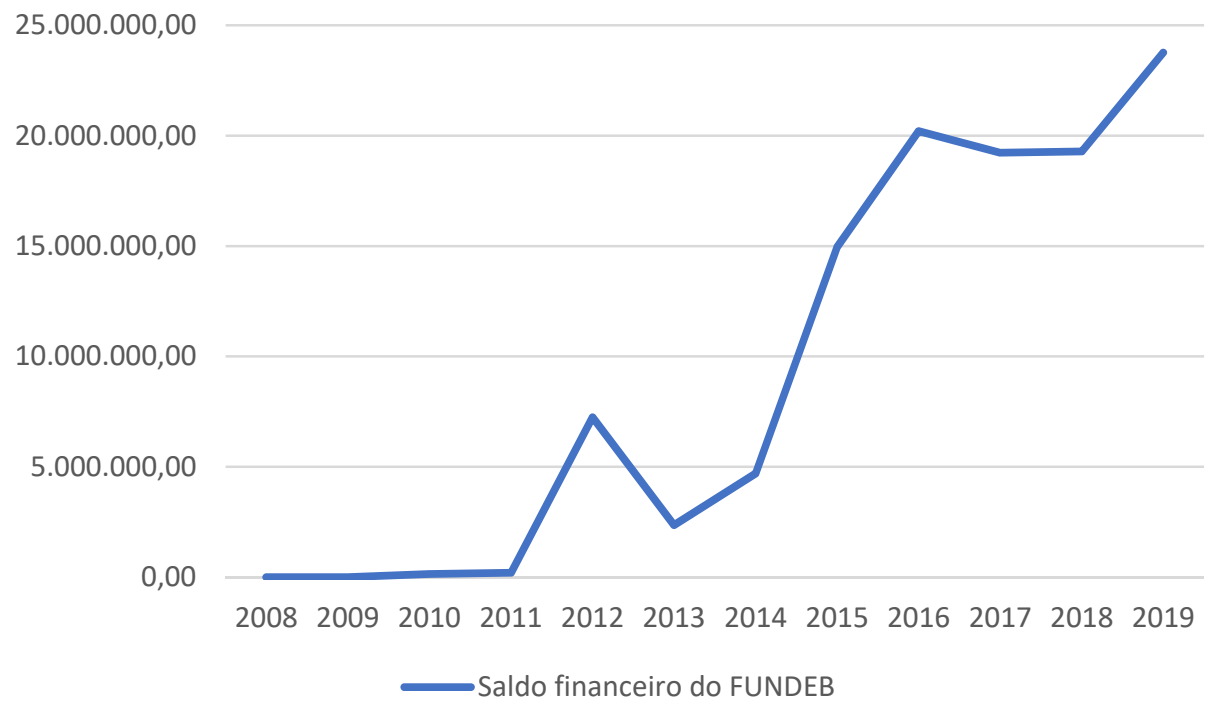

Fonte: Elaboração dos autores a partir do SIOPE. 
Repercussões do Fundeb no Acesso e na Oferta da Educação Infantil

A maior parte dos recursos próprios vinculados tem sido, por todo o período analisado, destinado ao ensino fundamental (Figura 3). É possível visualizar que a partir de 2009, ano no qual a pré-escola passa a ser de oferta obrigatória, por meio da EC $n^{\circ} 59 / 2009$, mais recursos começam a ser aplicados na educação infantil, chegando a seu maior percentual em 2015, mas não se mantendo no mesmo patamar nos anos subsequentes.

Figura 3 - Percentual de destinação dos recursos totais por etapa em Ribeirão das Neves

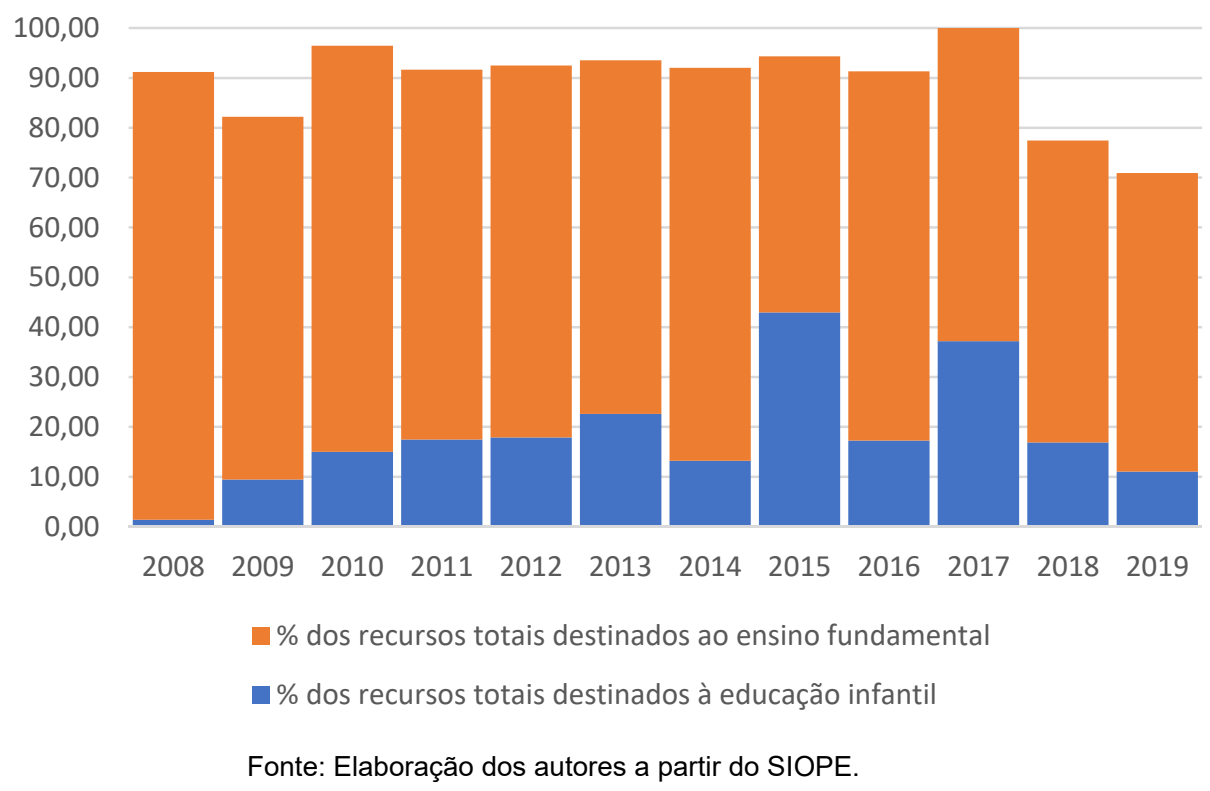

Quando analisados apenas os dados referentes aos recursos do Fundeb, é possível distinguir que, ao longo da série histórica, há uma ampliação significativa no percentual do fundo destinado à educação infantil, chegando, inclusive, no ano de 2015, a superar os valores alocados para o ensino fundamental, conforme pode ser observado no gráfico abaixo.

Figura 4 - Evolução dos gastos de recursos do Fundeb por etapa em Ribeirão das Neves

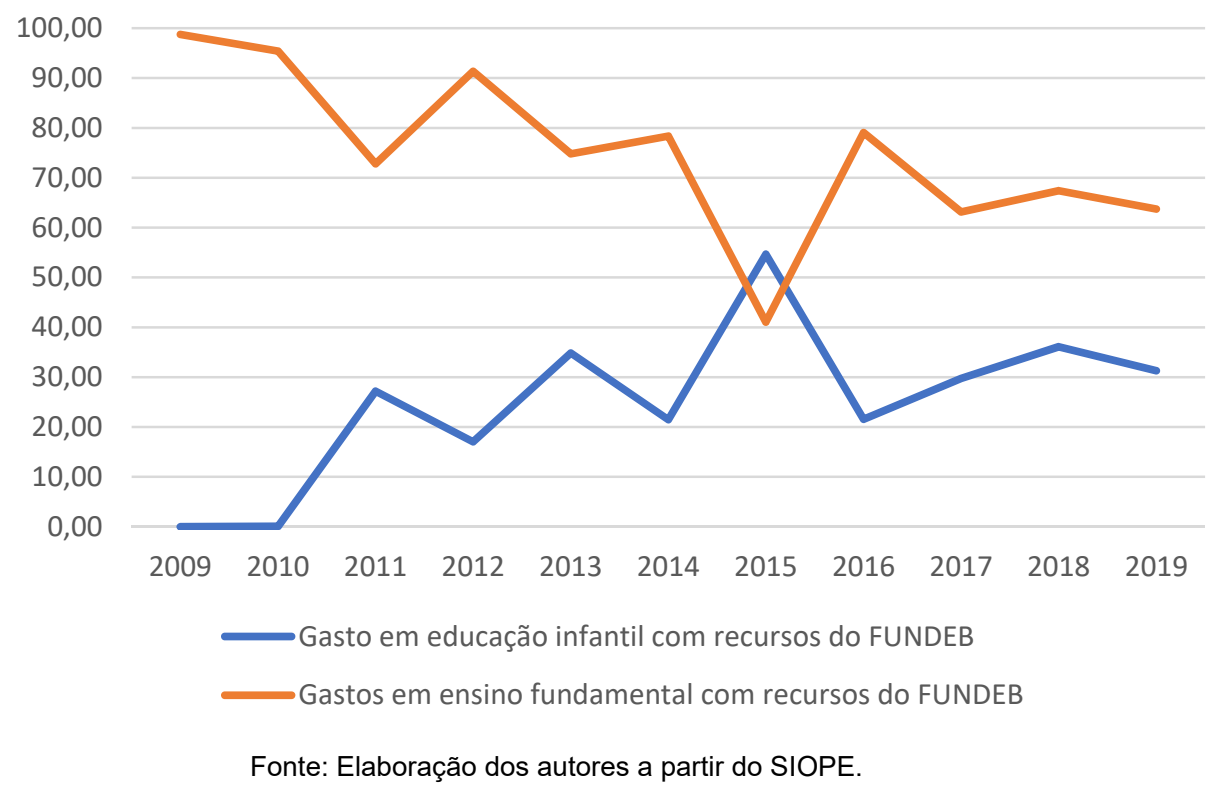


Repercussões do Fundeb no Acesso e na Oferta da Educação Infantil

Os gastos com pagamento de professores utilizando recursos do fundo também demonstram que o Fundeb ampliou a destinação orçamentária para essa rubrica (Figura 5).

Figura 5 - Evolução dos gastos de recursos do Fundeb com pagamento de professores por etapa em Ribeirão das Neves, corrigidos pelo IPCA, dez./2019

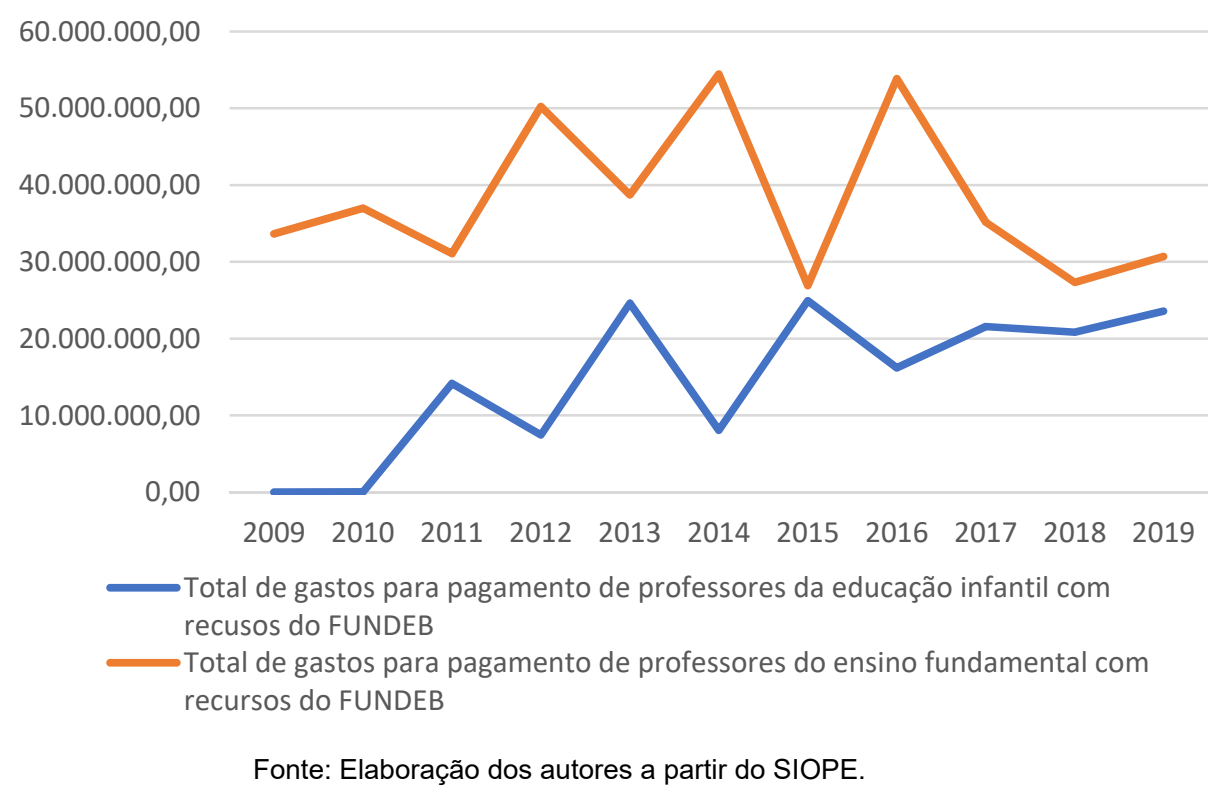

Em comparação aos gráficos anteriores, apenas no tocante a outras despesas educacionais, o Fundeb, ao final da série histórica, não produziu uma ampliação tão significativa (Figura 6). A exceção se verifica entre os anos 2013 e 2015, quando o total de gastos com a primeira etapa da educação básica foi superior ao destinado para o ensino fundamental. Em 2019, a diferença entre o investido na educação infantil e o ensino fundamental $(4,41 \%$ e $28,78 \%$, respectivamente) voltou a patamares próximos aos de 2009 ( $0,04 \%$ e $35,84 \%$ do total de recursos do Fundeb, respectivamente).

Figura 6 - Evolução dos gastos de recursos do Fundeb com outras despesas educacionais por etapa em Ribeirão das Neves, corrigidos pelo IPCA, dez./2019

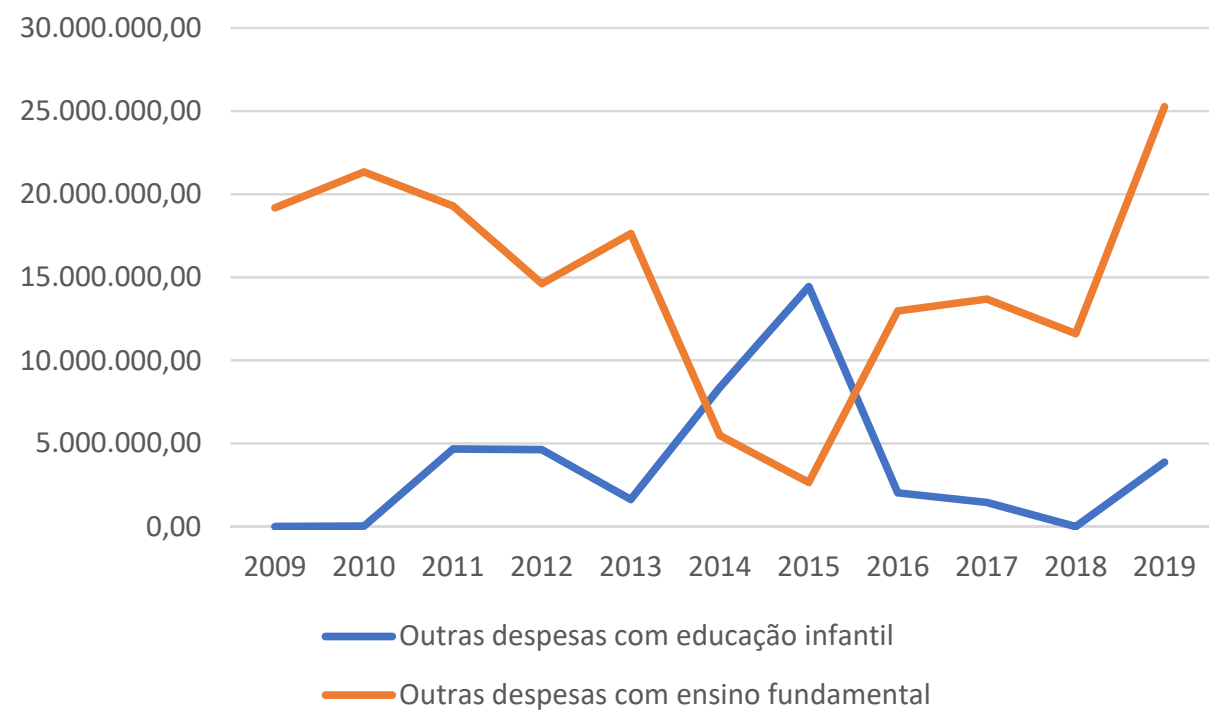

Fonte: Elaboração dos autores a partir do SIOPE. 
Repercussões do Fundeb no Acesso e na Oferta da Educação Infantil

A análise do total de recursos da educação destinados às duas primeiras etapas da educação básica, quando cotejado com os gráficos anteriores, sugere que, após a crise arrecadatória do estado (2012) e a crise econômica que o país passou no final de 2014 e 2015, o valor gasto por aluno efetivado na educação infantil e no ensino fundamental se aproximou, como revela o gráfico da Figura 7. Ou seja, a diferença do valor ano por aluno que, em valores corrigidos de 2008 , era de $R \$ 5.465,72$ ( $R$ \$ 197,17 da educação infantil e $R \$$ $5.662,89$ do ensino fundamental), em 2019 passou a ser de $R \$ 483,79$ ( $R \$ 2.650,02$ da educação infantil e $R \$ 3.133,81$ do ensino fundamental), uma redução de mais de $1000 \%$.

Figura 7 - Evolução do valor aluno ano efetuado por etapa em Ribeirão das Neves, corrigido pelo IPCA, dez./2009

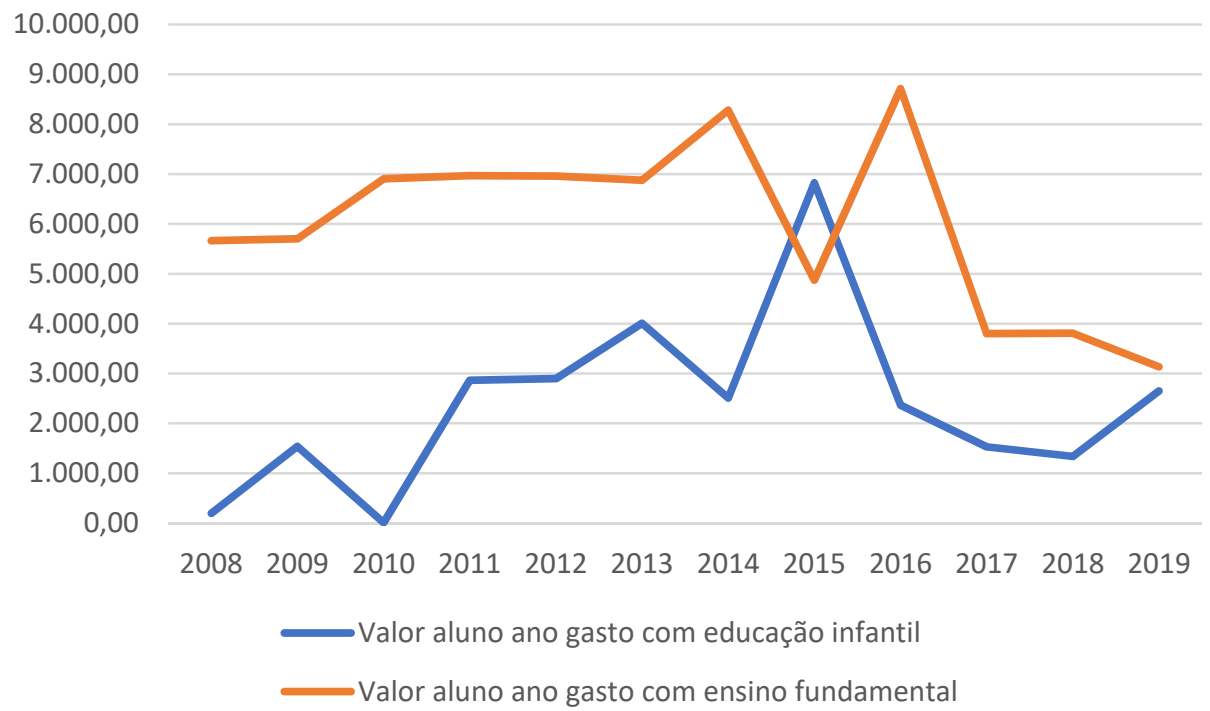

Fonte: Elaboração dos autores a partir do SIOPE.

Porém, quando se analisa a composição de cada gasto de forma desagregada, é possível dimensionar que a fonte orçamentária que tem garantido o aumento dos recursos para a educação infantil (mesmo que ainda abaixo do adequado) concentra-se nos recursos provenientes do Fundeb.

Figura 8 - Composição dos recursos destinados à educação infantil em Ribeirão das Neves

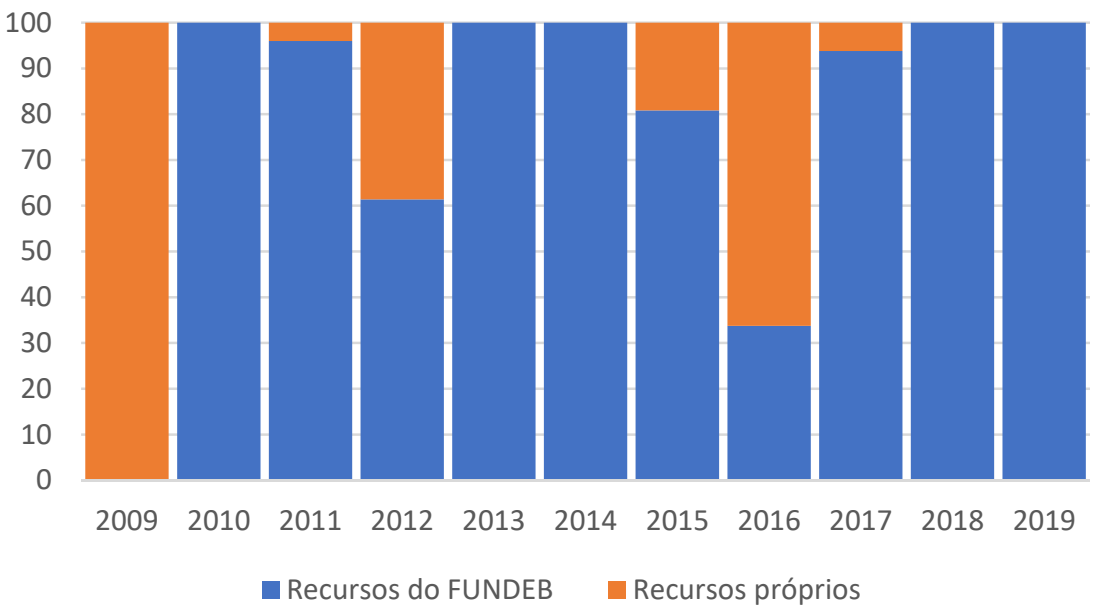

Fonte: Elaboração dos autores a partir do SIOPE. 
Repercussões do Fundeb no Acesso e na Oferta da Educação Infantil

Os dados revelam que, do total de recursos gastos em educação infantil no município de Ribeirão das Neves no período analisado, em geral, o orçamento é composto majoritariamente por recursos advindos do Fundeb. Constituem-se exceções 2009, ano em que a oferta da pré-escola se torna obrigatória; 2012, ano de forte crise fiscal no estado e queda na arrecadação de ICMS, o que parece ter obrigado ao município investir recursos próprios para a manutenção das creches e pré-escolas; e 2015, quando da crise econômica em nível nacional. Imediatamente após recuperação orçamentária, o município voltava a destinar para a educação infantil recursos provenientes quase que totalmente, retirados do fundo.

Essa configuração das fontes de receitas e despesas sugere forte dependência do acesso e da oferta da educação infantil em Ribeirão das Neves à existência do Fundeb. A próxima seção investiga o acesso e a oferta da educação infantil em Ribeirão das Neves buscando perceber as relações dessas dimensões com o fundo.

\section{Acesso e Oferta da Educação Infantil em Ribeirão das Neves}

Tendo em vista o inciso VII do artigo 206 da CF/88 da garantia do padrão de qualidade, esse atendimento precisa ser feito assegurando duas dimensões: capacidade de oferta e condições de oferta. Por capacidade de oferta, entende-se a existência de vagas suficientes para o atendimento do total de crianças em idade regulamentar. No entanto, essas vagas não podem ser oferecidas de qualquer maneira, mas mediante padrões mínimos de qualidade, ou seja, condições de oferta.

Esta seção analisa a capacidade de oferta de educação infantil do município de Ribeirão das Neves, medida pela expansão da matrícula de crianças de 0 a 5 anos nas creches e préescolas. Analisa também as condições de oferta da primeira etapa da educação básica a partir de duas categorias: infraestrutura das escolas e remuneração de professores.

\subsection{Expansão das matrículas em creches e pré-escolas municipais}

A oferta da educação infantil é competência prioritária municipal, por determinação constitucional, devendo o município contar com cooperação técnica e financeira da União e dos estados.

Segundo o Observatório do Plano Nacional de Educação (OPNE) no ano de 2018, o Brasil apresentou uma taxa de $93,8 \%$ das crianças de quatro e cinco anos e $35,6 \%$ das crianças de zero a três anos matriculadas, respectivamente, em pré-escolas e creches. No âmbito estadual, Minas Gerais demonstrou que $94,6 \%$ das crianças de quatro e cinco anos e $35,8 \%$ das crianças de zero e três anos se encontram matriculadas. Tais dados demonstram que garantir o acesso às creches tem sido o principal desafio das políticas educacionais. Segundo Cruz, Farah e Sugiyama (2014, p. 208),

Os serviços de creche podem ser oferecidos pela rede pública ou pela rede privada. A oferta pela rede privada se dá por meio de duas modalidades: a) lucrativa, em que a oferta é feita diretamente pelo setor privado, sendo regulada pelo mercado; e b) 'sem fins lucrativos', em que os serviços são ofertados por instituições comunitárias, confessionais ou filantrópicas, por meio, em geral, de convênios firmados com o Poder Público. Nesse caso, as creches conveniadas contribuem com a materialização da política municipal e ampliam a oferta de vagas. 
Repercussões do Fundeb no Acesso e na Oferta da Educação Infantil

De acordo com o Censo Escolar do Instituto Nacional de Estudos e Pesquisas Anísio Teixeira (INEP), no período de análise desta pesquisa Ribeirão das Neves teve um aumento de $26,8 \%$ no número de escolas que ofertavam educação infantil. Em números absolutos, em 2009 , havia 49 escolas infantis e, em 2019, 67 . Esse crescimento foi proporcionalmente maior no segmento das creches do que nas pré-escolas (33,3\% e 19,6\%, respectivamente) e na iniciativa privada em relação à pública $(29,4 \%$ e $26,0 \%$, respectivamente). O gráfico da Figura 9 demonstra essa evolução.

Figura 9 - Evolução do número de instituições de educação infantil em Ribeirão das Neves

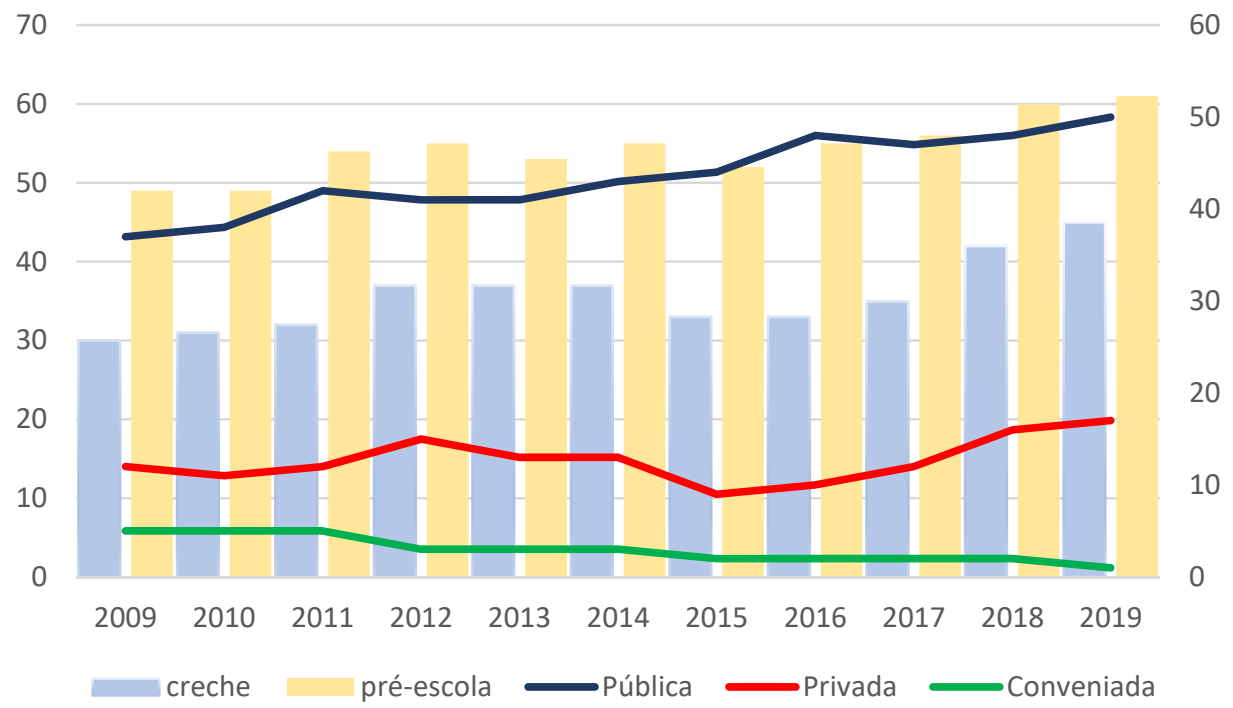

Fonte: Elaboração dos autores a partir de dados dos censos escolares do INEP.

Na comparação com o gráfico do saldo do Fundeb no município (Figura 2), é possível visualizar que os dois picos mais perceptíveis da evolução do número de escolas de educação infantil (entre 2009 e 2011; e entre 2015 e 2016) se dão exatamente nos momentos de maior elevação proporcional do fundo. Por outro lado, ao se cotejar com os dados da Figura 8, são os dois períodos nos quais também há o maior percentual de recursos próprios para a educação infantil. Uma das possíveis interpretações seria um maior esforço do município para ampliar a rede de atendimento após a EC 59/2009 e a aproximação do prazo do PNE em relação à meta 1 de atendimento de $100 \%$ das crianças de 4 a 5 anos nas pré-escolas. Ou seja, o advento de mais recursos provenientes do fundo, conjugados com a destinação de uma maior fatia do orçamento vinculado próprio, repercutiu em um aumento do número de escolas de educação infantil.

Em outro aspecto, as crises financeiras afetaram mais as escolas privadas no tocante ao número de escolas, que apresentaram queda contínua entre 2012 e 2015 . Já as escolas conveniadas foram se reduzindo desde 2011, restando apenas uma no município em 2019. As crises não diminuíram o número total da rede pública, mas se constituíram obstáculo em sua expansão, como pode ser visto na manutenção do número de instituições de creches e pré-escolas entre 2012 e 2013 (crise fiscal do estado) e entre 2016 e 2018 (reflexos da crise econômica pela qual atravessou o País).

Quanto ao número de matrículas, no ano de 2009 foram realizadas 6695 matrículas de crianças entre zero e cinco anos, considerando a rede pública e privada, no ano de 2019 esse 
Repercussões do Fundeb no Acesso e na Oferta da Educação Infantil

número foi de 11536 matrículas no total, representando um aumento de $72 \%$ no período estudado. Vale ressaltar que a maior parte dessas matrículas está concentrada na rede pública do município. O gráfico da Figura 10 demonstra esse crescimento.

Figura 10 - Evolução do número de matrículas de educação infantil em Ribeirão das Neves

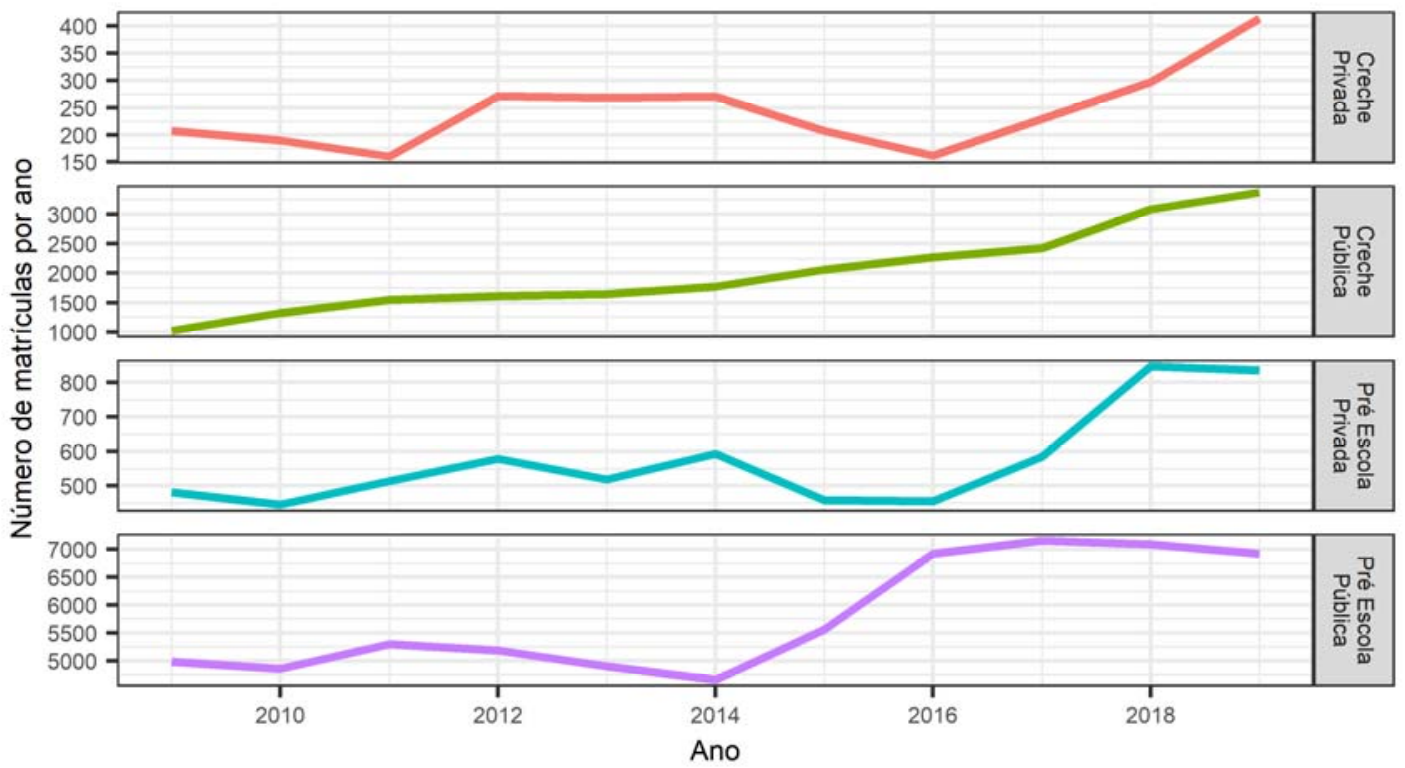

Fonte: Elaboração dos autores a partir de dados dos censos escolares do INEP.

Essa evolução no número total de matrículas pode ser explicada principalmente pelo crescimento linear observado ao longo dos anos no número de matrículas em creches públicas. Houve um crescimento de $229 \%$ no período, passando de 1024 matrículas em 2009 para 3369 matrículas em 2019.

Em relação ao número de matrículas em creches e pré-escolas privadas, estas apresentaram um aumento de $100 \%$ e $74 \%$ respectivamente. As creches privadas passaram de 207 para 414 matrículas em 2019, enquanto as pré-escolas privadas tiveram um crescimento percentual menor, passando de 481 matrículas para 835 em 2019. Porém, apesar do aumento, é interessante notar que essas duas classes sofreram quedas durante o período, como pode ser observado no Gráfico 10, em 2015 ambas fecharam o número de matrículas com queda de $23 \%$ em relação ao ano anterior. Enquanto a rede pública não sofreu com quedas, pelo contrário, registraram aumento no número de matrículas em relação ao ano anterior.

\subsection{Infraestrutura das escolas de educação infantil}

A análise da infraestrutura das creches e pré-escolas de Ribeirão das Neves foi feita por meio dos dados informados pelos diretores nos censos escolares do INEP. Os dados foram discriminados em dois grupos de análise: i) serviços públicos (atendimento de água, energia elétrica, saneamento básico, coleta de lixo e esgoto); e ii) instalações e dependências (local de funcionamento, sanitários, espaços físicos, espaços de convivência infantis, bibliotecas e salas de leitura, atendimento educacional especializado).

A partir dos dados do censo, foi possível identificar na série histórica que Ribeirão das Neves conseguiu, em um primeiro momento, melhorar a adequação da infraestrutura de sua 
Repercussões do Fundeb no Acesso e na Oferta da Educação Infantil

rede de educação infantil quanto aos serviços públicos de água, energia elétrica e saneamento básico (Figura ). O gráfico revela que essa adequação se deu de maneira acentuada quando o Fundeb começou a compor significativamente os recursos da educação infantil, notadamente, como já discutido, a partir de 2011.

Os serviços de água e energia eram realizados em todas as escolas públicas e conveniadas do município, sendo que somente nos últimos anos da série histórica o percentual ficou abaixo de $100 \%$ e isso se deu exatamente nas novas escolas criadas no final da década (Figura 9), sendo que, no ano seguinte à implementação, os serviços nessas escolas foram normalizados. O mesmo não ocorreu com o tratamento de esgoto e saneamento básico, que passou a diminuir após 2013, somente apresentando ligeira melhora nos períodos de ampliação do percentual de recursos provenientes do Fundeb e no último ano da análise. Ou seja, mesmo com o aumento do número de escolas, nos períodos de crise - quando o município investiu impostos próprios -, optou-se por alocar o orçamento em outras áreas, deixando a adequação do saneamento básico ${ }^{2}$ das novas escolas para períodos em que o aporte do Fundeb voltasse a ocorrer.

Figura 11 - Evolução da infraestrutura de serviços públicos das instituições públicas e conveniadas de educação infantil de Ribeirão das Neves

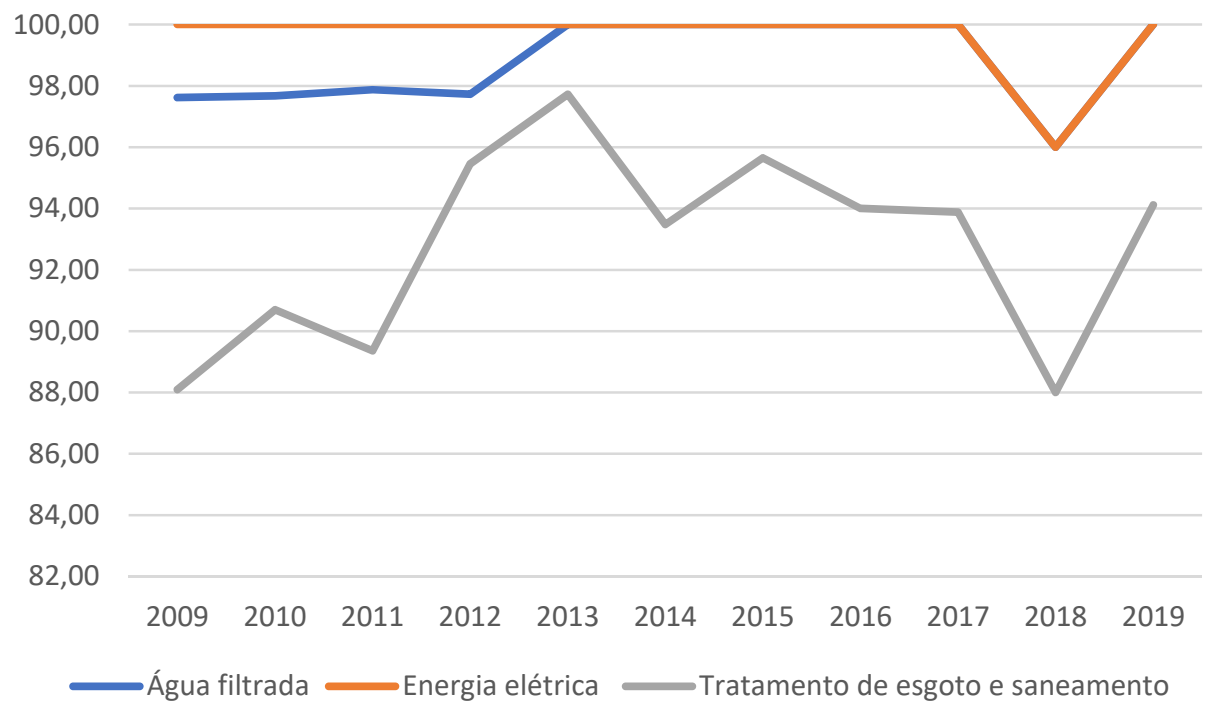

Fonte: Elaboração dos autores a partir de dados dos censos escolares do INEP.

As instalações e dependências das escolas de educação infantil em 2019 estão, em geral, aquém das condições de qualidade preconizadas pelos parâmetros básicos de infraestrutura do Ministério da Educação (2006). Apenas há universalidade no quesito da existência de dependências administrativas como sala de diretoria, secretaria e sala de professores, presentes em todas as escolas públicas e conveniadas de Ribeirão das Neves. Outros dois elementos estão em situação adequada para mais de $90 \%$ das escolas, o funcionamento em prédios escolares e bibliotecas/salas de leitura. Mesmo assim, em 2019 ainda havia no município escolas funcionando em igrejas, empresas, galpões ou mesmo na casa de professores, assim como escolas sem nenhum espaço de leitura.

2 Os dados de saneamento dizem respeito às instalações presentes na escola, conforme caderno de instruções do Censo Escolar (2018). 
Repercussões do Fundeb no Acesso e na Oferta da Educação Infantil

Em 2019, uma em cada três escolas $(34,4 \%)$ não tinha banheiro adaptado para crianças. Aproximadamente três em cada cinco não tinham parque infantil $(58,2 \%)$ e pouco mais da metade das creches $(56,8 \%)$ não tinha berçário. O elemento de infraestrutura com piores taxas de adequação é o de atendimento educacional de crianças com deficiência em espaços próprios, que, em 2019, somente estava disponível em uma a cada 5 escolas de educação infantil do município (21\%).

Quando analisada na perspectiva da série histórica (2009-2019), é possível perceber uma paulatina melhora de todos os quesitos, sendo que a maior variação de adequação foi na adequação de banheiros adaptados para crianças (melhora de $47,6 \%$ ) e, a menor, em parques infantis (melhora de 5,4\%). A evolução dos itens analisados está demonstrada no gráfico da Figura .

Figura 12 - Evolução dos percentuais de adequação de itens de infraestrutura de instituições públicas e conveniadas de educação infantil de Ribeirão das Neves

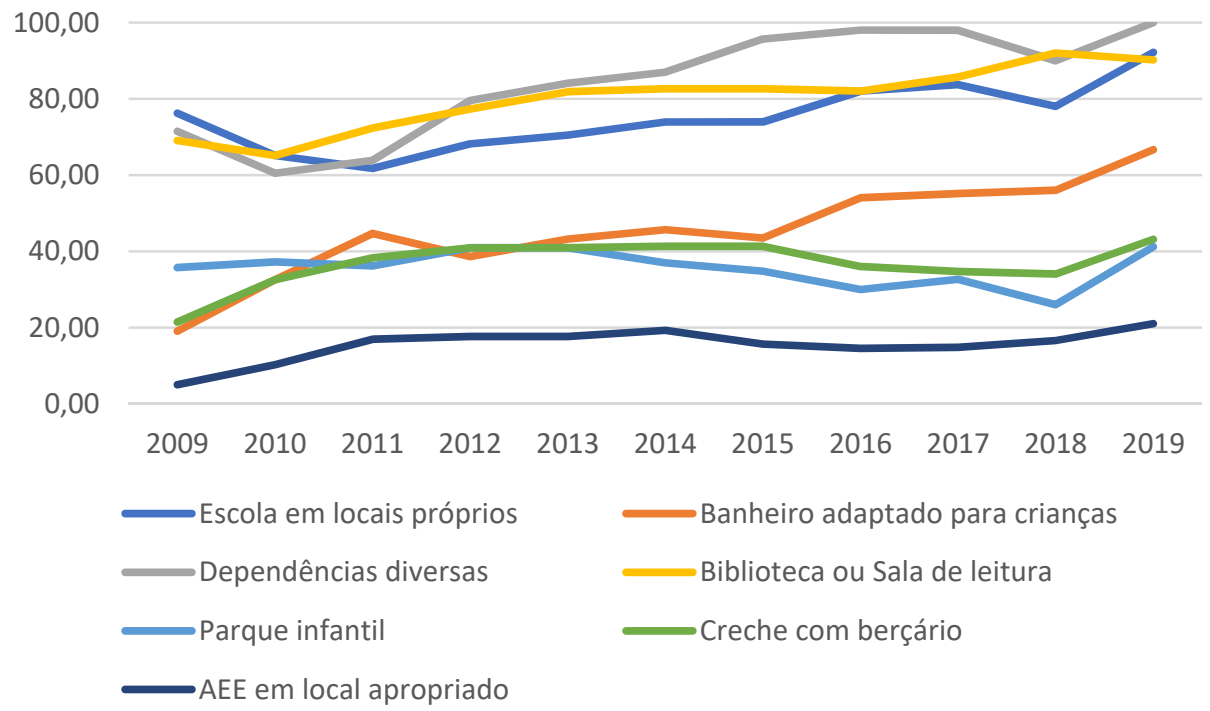

Fonte: Elaboração dos autores a partir de dados dos censos escolares do INEP.

A pequena, mas contínua, melhoria dos itens de infraestrutura apresenta dois momentos de maior inflexão na série histórica, entre 2009 e 2011; e em 2015, períodos que coincidem com o aumento de investimentos em outras despesas com recursos do Fundeb. Porém, o cotejamento dos dados sugere que, apesar de ser a rubrica com menor investimento dos recursos do Fundeb (Figura 6), ainda assim a melhoria da infraestrutura está associada ao fundo.

\subsection{Remuneração de professores da educação infantil}

A análise da remuneração dos professores da educação infantil do município de Ribeirão das Neves foi feita a partir de dados da Relação Anual de Informações Sociais (RAIS), do antigo Ministério do Trabalho e Emprego e Previdência Social (MTE).

O gráfico da Figura 13 demonstra visualmente os dados da evolução da média remuneratória dos professores da educação infantil de Ribeirão das Neves por sua formação. Os valores corrigidos demonstram que, até 2014, a remuneração dos docentes da primeira etapa da educação básica ficou acima do estabelecido pelo piso salarial profissional nacional 
Repercussões do Fundeb no Acesso e na Oferta da Educação Infantil

(PSPN) quando se padroniza a carga horária semanal para 40 horas (a jornada do município é 30 horas semanais). Em 2015, ano em que a crise econômica do País reduziu os recursos de transferências (e do Fundeb), conforme discutido anteriormente, a média remuneratória se reduz e passa a ficar abaixo do PSPN até o final da série histórica.

Figura 13 - Evolução da remuneração, por nível de formação, de professores da educação infantil de Ribeirão das Neves, corrigidos pelo IPCA, dez./2019

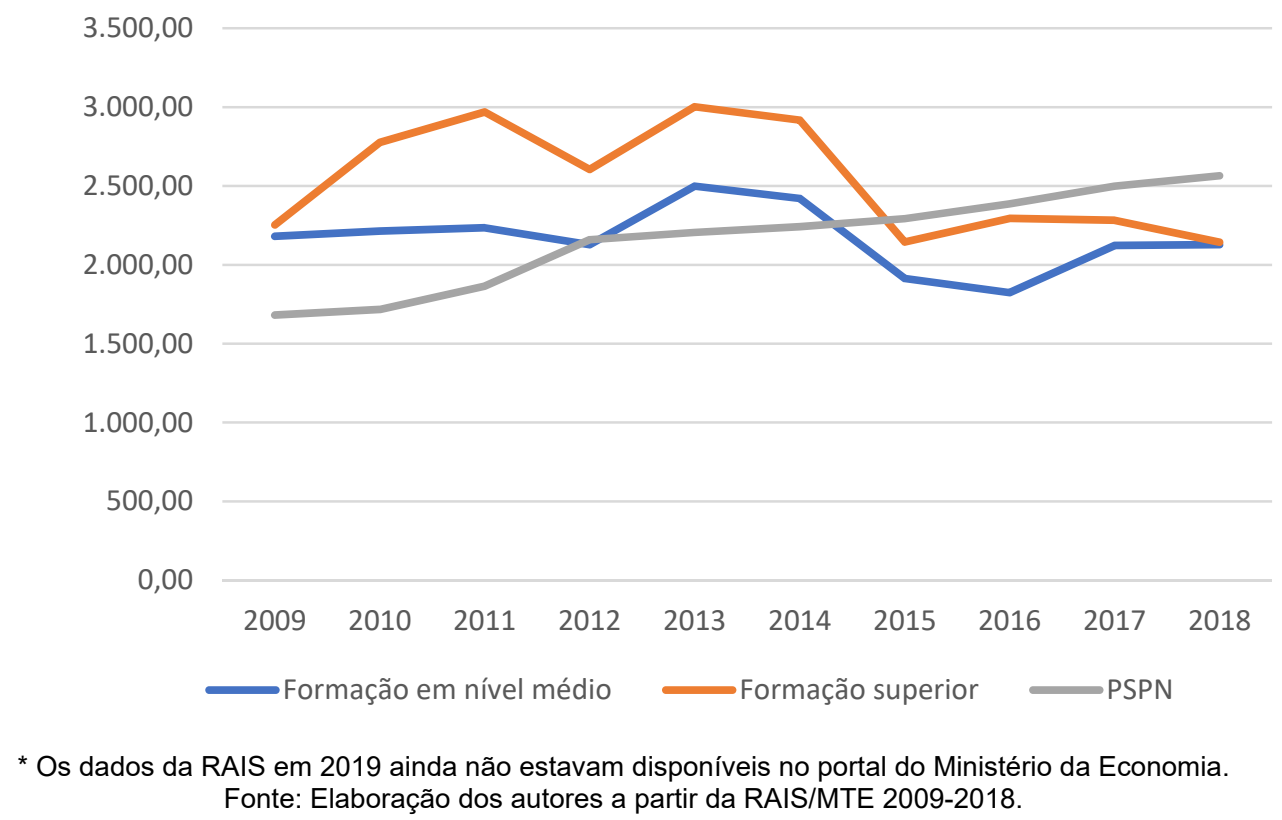

Os períodos de maior aumento também coincidem com os de avanço dos gastos do Fundeb na educação infantil (Figura 5). Porém, as linhas de 2016 e anos subsequentes não apresentam inclinação positiva. A possível explicação para esse fato, isto é, para o aumento dos gastos com pagamento de professores sem o aumento remuneratório médio é o aumento do número absoluto de professores contratados para as novas escolas. O aumento da remuneração média de professores sem formação em relação aos com formação superior (até ao ponto de ser praticamente a mesma em 2019) também pode ser explicado em razão do fato de no último concurso para a etapa da educação infantil no município ter havido exigência de titulação em nível médio, Magistério. Nos anos seguintes, predominou no município uma política de contratação temporária. Ou seja, após alguns anos, o plano de carreiras dos concursados com Magistério fez com que a média remuneratória se ampliasse, enquanto a média da remuneração dos professores com contrato provisório, e, portanto, sem plano de carreiras, se aproximasse. 
Repercussões do Fundeb no Acesso e na Oferta da Educação Infantil

Figura 14 - Evolução da remuneração, por nível de formação e etapa de trabalho, de professores da educação infantil de Ribeirão das Neves, corrigidos pelo IPCA, dez./2019

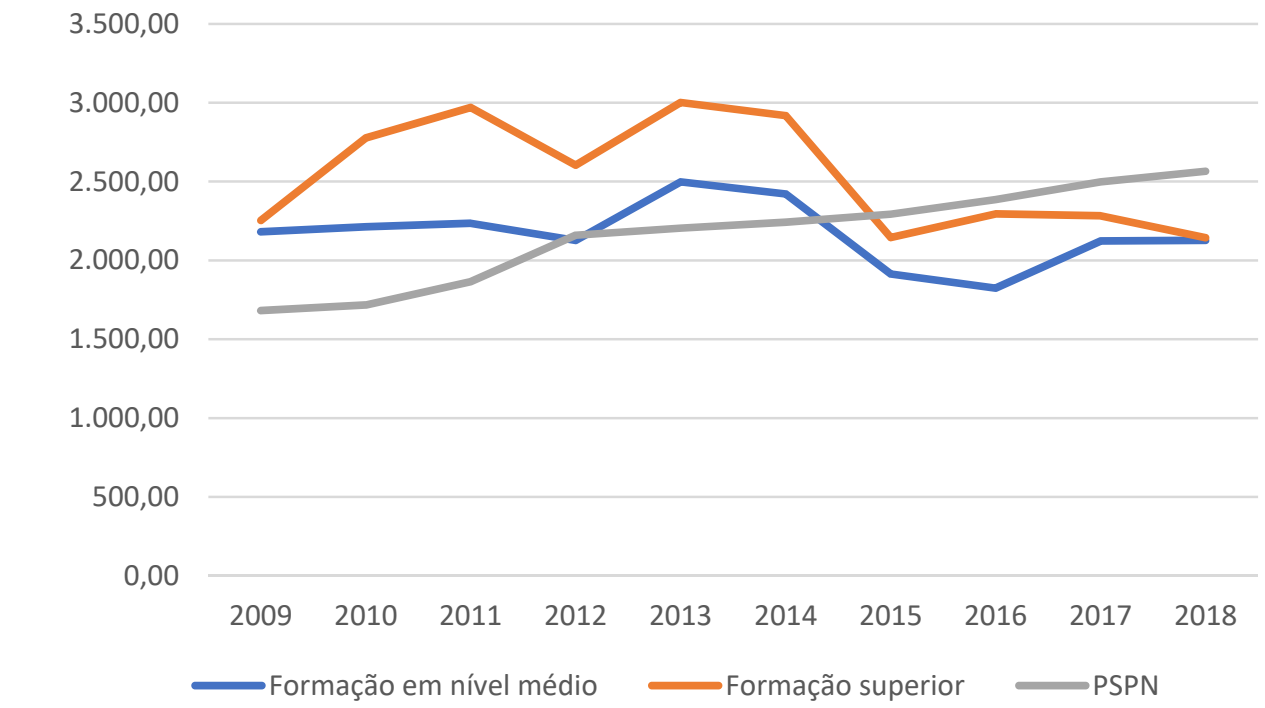

* Os dados da RAIS em 2019 ainda não estavam disponíveis no portal do Ministério da Economia. Fonte: Elaboração dos autores a partir de dados da RAIS/MTE 2009-2018.

O gráfico da Figura 14 aponta que, enquanto houve uma queda no valor médio de professores de creches, ocorreu um aumento da remuneração média dos professores das pré-escolas municipais de Ribeirão das Neves. O único período em que o valor médio ficou próximo foi entre 2015 e 2016, mas logo em seguida os valores se diferenciaram novamente, permanecendo assim até o final da série. Uma das possíveis explicações pode também ser os contratos provisórios, mais frequentes entre os professores que atendem as crianças de 0 a 3 anos do que entre os que atendem as crianças de 4 e 5 nas creches.

\section{Considerações Finais}

A proximidade do encerramento da vigência do Fundeb tem suscitado reflexões sobre a necessidade desse instrumento contábil para o financiamento da educação básica brasileira face à estrutural desigualdade econômica e social do país. A literatura tem apontado que os municípios, responsáveis pelo atendimento da educação infantil e do ensino fundamental (este em colaboração com os estados), serão os mais afetados em eventual encerramento do fundo, dado que são os entes federativos com menor poder arrecadatório e com maior desigualdade fiscal entre si. Este trabalho buscou contribuir com a discussão sobre o Fundeb permanente ao empreender um estudo de caso, no qual se analisaram as repercussões dessa política pública na educação infantil no município de Ribeirão das Neves em três dimensões: matrículas, infraestrutura e remuneração docente.

Foi possível perceber que a constituição histórica da educação infantil como direito foi marcada por descontinuidades, e que, apenas muito recentemente, essa etapa da educação básica se consolidou no campo do ordenamento jurídico educacional brasileiro. Outros obstáculos, em especial o orçamentário, propiciaram uma expansão desigual (e insuficiente) da oferta de creches e pré-escolas pelos entes subnacionais da federação, com destaque para os municípios mais pobres. Ribeirão das Neves é um exemplo de como a questão fiscal 
Repercussões do Fundeb no Acesso e na Oferta da Educação Infantil

se tornou um empecilho para a garantia do direito à educação infantil. Por ser um município de grande porte, com um número significativo de crianças de 0 a 5 anos, mas com baixo poder arrecadatório, a cidade ampliou de modo vagaroso seu atendimento aos bebês e crianças pequenas nas creches e pré-escolas. Os dados apontaram para o aumento mais significativo na oferta de vagas na educação infantil pública no município com o passar dos anos, no período de vigência do Fundeb.

O fundo, por seu desenho redistributivo, foi se tornando, ao longo de sua vigência, o elemento mais importante da composição orçamentária do município. Os dados apontaram que, à medida que os recursos do fundo cresciam, aumentava também sua destinação para a primeira etapa da educação básica, sendo o Fundeb a fonte orçamentária de maior peso na educação infantil. Os anos de maior crescimento dos recursos do fundo coincidem com o aumento da construção de estabelecimentos escolares públicos e com a evolução das matrículas nas creches e principalmente nas pré-escolas. No tocante à adequação da oferta, a partir do momento em que o Fundeb passou a compor significativamente os recursos destinados à educação infantil, todos os elementos de infraestrutura apresentaram melhora contínua durante a vigência do fundo (com exceção de tratamento de esgoto e saneamento básico). Quanto aos docentes, à medida que se aumentaram os recursos do fundo, estes passaram a ser utilizados para se ampliar a contratação de professores temporários, sem perceptível aumento salarial, que se manteve abaixo do valor do PSPN a partir de 2014, mesmo com crescimento progressivo de recursos do fundo para pagamento do magistério público.

Dessa forma, é possível concluir que o Fundeb foi elemento fundamental na expansão da educação infantil no município de Ribeirão das Neves, que, como município com baixa capacidade de atendimento institucional protegido, é dependente do efeito redistributivo do fundo. Os dados sugerem que essa política repercutiu positivamente, pois, ao assegurar recursos ao município, possibilitou a garantia do direito de crianças de 0 a 5 anos à educação. Uma vez que este estudo de caso analisou um município que teve ganhos com o Fundeb, são necessárias outras análises que investiguem os efeitos do fundo em municípios de diferentes portes demográficos e fiscais, assim como em municípios com perdas fiscais pelo fundo, de forma que seja possível o cotejamento e a avaliação de impacto da política.

O Fundeb, a despeito da sua contribuição na ampliação do atendimento na educação infantil, por si só, não é capaz de resolver todos os problemas educacionais. Como os dados desvelaram, permanecem no município de Ribeirão das Neves desafios a serem superados, tais como a matrícula de pelo menos $50 \%$ das crianças de 0 a 3 anos e sua universalização para as crianças de 4 e 5 anos, conforme preconizado no Plano Nacional de Educação vigente; a adequação da infraestrutura de todas as creches e pré-escolas, garantindo o padrão de qualidade previsto no inciso VII do artigo 206 da CF/88 e inciso IX do artigo 4 da LDB; e o pagamento do PSPN para todos os professores, assegurado pela lei 11.738/08. Se com o Fundeb esses desafios permanecem, sendo necessárias novas políticas públicas educacionais que se somem ao fundo; sem o Fundeb dificilmente os obstáculos à educação infantil em específico, e da educação básica brasileira em geral, serão superados. 
Repercussões do Fundeb no Acesso e na Oferta da Educação Infantil

\section{Referências}

ARELARO, L. Fundef: uma avaliação preliminar dos dez anos de sua implementação. In: REUNIÃO ANUAL DA ANPED, 30., 2007, Caxambu. Anais... Caxambu, 2007.

ARRETCHE, M. T. S. Políticas sociais no Brasil: descentralização em um estado federativo. Revista Brasileira de Ciências Sociais, São Paulo, v. 14, n. 40, p. 111-141, jun. 1999.

BRAGA, D. S.; SILVA, D. C. A. Repercussões do Fundeb em Municípios Mineiros: aportes para a discussão sobre um Fundeb permanente. FINEDUCA - Revista de Financiamento da Educação, Porto Alegre, 9, n. 3, 2019.

BRASIL. Constituição da República Federativa do Brasil de 1988. Diário Oficial da União, Brasília, 1988.

BRASIL. Lei $n^{\circ}$ 9.394, de 20 de dezembro de 1996. Estabelece as diretrizes e bases da educação nacional. Diário Oficial da União, Brasília, 1996a.

BRASIL. Lei $n^{\circ}$ 9.424, de 24 de dezembro de 1996. Dispõe sobre o Fundo de Manutenção e Desenvolvimento do Ensino Fundamental e de Valorização do Magistério, na forma prevista no art. $60, \S 7^{\circ}$, do Ato das Disposições Constitucionais Transitórias, e dá outras providências. Diário Oficial da União, Brasília, 1996b.

BRITO, V. L. F. A. de; BRAGA, D. S. Recursos para a educação e limites do ajuste fiscal. Educação em Revista, Belo Horizonte, v. 32, p. 247-266, 2016.

BUENO, E. N.; PERGHER, C. J. Analisando a Trajetória dos Fatores de Ponderação Estabelecidos no Fundeb: 2007-2016. FINEDUCA - Revista de Financiamento da Educação, Porto Alegre, v. 7, p. 01-18, 2017.

CAMPOS, M. M.; ROSEMBERG, F.; FERREIRA, I. M. Creches e pré-escolas no Brasil. São Paulo: Cortez, 1995.

CARA, D. O Custo Aluno-Qualidade Inicial como proposta de justiça federativa no PNE: Um primeiro passo rumo à educação pública de qualidade no Brasil. Jornal de políticas educacionais, n. 16, p. 75-91, jul./dez. 2014.

COSTA, B. L. D.; DUARTE, V. C. Os efeitos do FUNDEF nas políticas educacionais dos municípios mineiros. Educação em Revista, Belo Horizonte, v. 48, n. 1, p. 143-170, dez. 2008.

CRUZ, M. do C. M. T.; FARAH, M. F. S.; SUGIYAMA, N. B. Normatizações Federais e a Oferta em creches no Brasil. Estudo em Avaliação Educacional, São Paulo, v. 25, n. 59, p. 202241, set./dez. 2014.

DIMENSTEIN, G. Mobilizadores do ‘Fundeb pra Valer' são recebidos em Brasília. Folha UOL, São Paulo, 2005. Disponível em: <http://www1.folha.uol.com.br/folha/dimenstein/ noticias/gd010905.htm>. Acesso em: 28 maio 2020.

FREIRE, M. M. de L.; LEONY, V. da S. A caridade científica: Moncorvo Filho e o Instituto de Proteção e Assistência à Infância do Rio de Janeiro (1899-1930). Hist. cienc. saúdeManguinhos, Rio de Janeiro, v. 18, sup. 1, p. 199-225, 2011. 
Repercussões do Fundeb no Acesso e na Oferta da Educação Infantil

GOMES, F. A. IPTU - Melhoria da arrecadação do município de Ribeirão das Neves-MG. Brasília, 2018.

KRAMER, S. A Política do Pré-Escolar no Brasil: a arte do disfarce. Rio de Janeiro: Achiamé, 1984.

NUNES, M. F. R.; CORSINO, P.; DIDONET, V. Educação Infantil no Brasil: primeira etapa da educação básica. Brasília: UNESCO; Ministério da Educação; Secretária de Educação Básica; Fundação Orsa, 2011.

ROSEMBERG, F. A LBA, o Projeto Casulo e a Doutrina de Segurança Nacional. In: FREITAS, M. F. História social da infância no Brasil. 6. ed. São Paulo: Cortez, 2006.

SANTOS, J. B. dos. O Fundeb e a Educação Infantil. Curitiba: Appris, 2015. 187 p.

SANTOS, J. B. dos; SOUSA JUNIOR, L. de. O Financiamento da Educação Infantil no Fundeb: um estudo sobre o atendimento das crianças de 0 a 6 em João Pessoa/ PB. 2016.

SILVA, F. R. Educação Infantil não é Brincadeira: Valorização da Remuneração e Carreira do Professor para a Educação Infantil na Rede Municipal de Educação de Belo Horizonte (RME/BH) no Contexto do Financiamento Educacional (2004-2015). 2017. Dissertação (Mestrado em Educação) - Universidade do Estado de Minas Gerais, Belo Horizonte, 2017.

SILVA, F. R.; BRITO, J. E. de. Financiamento da Educação Infantil: Rumos da Produção do Conhecimento na Anpae, ANPEd e Fineduca (2016 A 2018). Pesquisa e Debate em Educação, Juiz de Fora, v. 9, n. 2, p. 763-787, dez. 2019.

SILVA, O. H. R.; STEPHAN, I. I. C. O Plano Diretor de Ribeirão das Neves - MG: Análise de uma Cidade Fora do Plano. Revista Nacional de Gerenciamento de Cidades, Minas Gerais, v. 03. n. 16, 2015.

SOSA, M. F. Território, identidade e política: os lugares de urbanidade metropolitana no contexto do planejamento urbano na região metropolitana de Belo Horizonte. 2018. Dissertação (Mestrado em Arquitetura e Urbanismo) - Universidade Federal de Minas Gerais, Belo Horizonte, 2018.

VIEIRA, L. M. F. Mal Necessário: creches no Departamento Nacional da Criança (1940-1970). Cadernos de Pesquisa, São Paulo, v. 17, n. 67, p. 3-16, nov. 1988.

Josielli Teixeira de Paula Costa é graduanda em Pedagogia pela Universidade Federal de Minas Gerais (UFMG). Membro do Núcleo de Pesquisas em Desigualdades Escolares (NUPEDE/UFMG) e do Centro de Estudos de Criminalidade e Segurança Pública (CRISP/UFMG).

ORCID: https://orcid.org/0000-0002-2345-6057

E-mail: josidpaula3@gmail.com

Franceline Rodrigues Silva é doutoranda no Programa de Pós-Graduação em Educação: Conhecimento e Inclusão Social, da Faculdade de Educação da UFMG (PPGE/FaE/UFMG). Mestre em Educação pela Universidade do Estado de Minas Gerais- UEMG (2018). Especialista em Educação Criativa pela Pontifícia Universidade Católica de Minas GeraisPUC-MG (2019). Graduada em Pedagogia pela UEMG. Atua como Professora da Educação 
Repercussões do Fundeb no Acesso e na Oferta da Educação Infantil

Infantil na Rede Municipal de Educação de Belo Horizonte-RME/BH- desde o ano de 2014 até os dias atuais e como tutora do curso de Pedagogia EAD/FaE/UEMG, desde novembro de 2019. Dedica-se a refletir sobre os seguintes temas de pesquisa: educação infantil, valorização de professores, financiamento da educação e metodologias ativas.

ORCID: http://orcid.org/0000-0003-0213-3192

E-mail: franceline.rodrigues30@gmail.com

Daniel Santos Braga é docente em cursos de formação de professores na Universidade do Estado de Minas Gerais (unidade Ibirité) e do Centro Universitário Newton Paiva. Doutorando em 'Educação: Conhecimento e Inclusão Social' pela Universidade Federal de Minas Gerais com pesquisa no campo de Políticas Públicas em Educação. Mestre em Educação e Formação Humana pela Universidade do Estado de Minas Gerais com pesquisa na área do Financiamento Público da Educação e a Valorização do Magistério. Graduado em Pedagogia no segundo semestre de 2016.

ORCID: http://orcid.org/0000-0001-5075-4570

E-mail: danielsantosbraga@gmail.com

Recebido em 30 de maio de 2020

Aprovado em 14 de julho de 2020 